\title{
Futebol e ferrovia: a história de um trem da industrialização que parte para o noroeste paulista
}

CDD. 20.ed. 796.3309

\author{
Marco Antonio Bettine de ALMEIDA* \\ Gustavo Luis GUTIERREZ ${ }^{* *}$ \\ Ricardo Pellison FERREIRA**
}

*Escola de Artes, Ciências e Humanidades, Universidade de São Paulo.

**Faculdade deEducação Física, Universidade de Campinas.

\section{Resumo}

0 artigo busca desenvolver a relação entre a expansão da rede ferroviária no interior paulista e a evolução das práticas esportivas, mais especificamente o futebol. A ideia central é que o movimento ocorre do meio urbano para o interior, percebido agora não mais como um espaço tradicionalmente rural, mas no bojo do surgimento e expansão de vilas e cidades. Procura apontar as principais características da realidade política, econômica e social do Brasil na primeira metade do século XX e contribuir para a discussão sobre o desenvolvimento das práticas esportivas no período.

UnITERMOS: História; Esporte; Futebol.

\section{Considerações iniciais}

Antes de discutir a questão chave deste artigo: a relação entre futebol e ferrovias; é preciso deixar claro os motivos de delimitar a análise do período entre o fim do século XIX até metade do século XX.

Para se ter ideia sobre a afinidade destes temas foi no inicio do século XX que o futebol chega ao Brasil através de Charles Miller. No ano de 1900 as fontes históricas citam a presença de algum tipo de prática ou modalidade esportiva na região do noroeste paulista. Alguns esportes são citados no "Álbum Illustrado da Comarca de Rio Preto" organizado por Cavalheiro, como únicas manifestaçōes esportivas da época. "Até então, a excepção de corridas de cavallos em raia rústica e impropria, dos esportes de caça e pesca, não conhecia a nossa cidade outros." (CaValheiro, p.12, 1929). CaValheiro (1929, p. 615) ao analisar a situação da Comarca de Rio Preto (noroeste paulista) faz a seguinte afirmação:

Commo aconteceu por todo o Estado, podemos quase affirmar o violento crescimento do esporte bretão, iniciado de 1907. Em São Paulo, mais ou menos em 1900, tomou foros de nacionalidade e surgiu por todos os recantos ameaçando quase a paralysação dos outros esportes, vindo fazer sua estréa em Rio Preto, lá pelos annos de 1907.

Como apontado na referência a prática do futebol inicia-se no começo do século XX, o mesmo se deu com a vinda da Estrada de ferro no noroeste paulista no final do século XIX e começo do século XX.

Na metade do século XX temos o "Maracanasso" que se apresenta como marco histórico da inserção cultural e social do futebol no Brasil, o brasilianista Thomas SKIDMORE (1996) descreve o evento como retrato simbólico da ligação de uma nação com uma modalidade esportiva. Este evento representa simbolicamente a difusão nas diversas classes sociaisde um esporte vindo da elite. Durante meio século o Brasil sofreu mudanças e a que mais se relaciona com a discussão deste trabalho foi a industrialização, carreada pela urbanização que influenciou a criação de clubes de futebol. Neste sentido, as ferrovias foram os meios pelos quais a industrialização chega ao interior do país, junto com o pensamento da prática esportiva e o futebol como consequência.

Nas próximas páginas vamos analisar o processo de expansão da prática do futebol no noroeste do Estado de São Paulo, tendo como método a interpretação de documentos e de literatura temática nos seguintes tópicos: contexto social do período, política, industrialização, ferrovias, cidades, noroeste paulista, clubes, esportes e futebol.

Todos estes temas não serão pensados como mera soma de descriçōes de experiências ou acontecimentos. 
Serão sistematizados no conjunto das pesquisas em ciências humanas, destacando seus atores fundamentais, permitindo ultrapassar o simples senso comum.

Assumir a importância da produção acumulada não significa defender o seu congelamento, como se fosse uma revelação impossível de superar, mas sim a procura da transformação.

A base teórica para a interpretação destes documentos parte da percepção de um sujeito da ação social que busca racionalmente fins objetivos. As instituições envolvidas serão estruturadas a partir do conceito de tipo ideal weberiano (WEBER, 1994), que consiste em exagerar e formar um entendimento comum do objeto para possibilitar interpretações sobre sua importância no cenário mais amplo. Os tipos ideais serão a industrialização, entendida como processo de produção industrial através da racionalização e uso da tecnologia para a produção em grande escala, atingindo um maior mercado consumidor. A ferrovia é entendida como parte deste processo de produção industrial, para escoamento das matérias primas e dos produtos industrializados. O esporte, enquanto tipo ideal, é compreendido como sistematização dos movimentos e das regras dos jogos populares, transformando-os em modalidades que possuem uma organização rígida que busca o confronto de pessoas, ou grupos de pessoas, para fins competitivos, com o objetivo último de obter a vitória. O futebol é entendido como uma modalidade específica do universo esportivo, criado dentro de um padrão de racionalização das condutas e sistematização das regras, com o propósito de possibilitar que a modalidade pudesse ser reproduzida em qualquer ambiente distinto de sua origem primeira.

Todos estes tipos têm como pressuposto a interrelação da produção, da competição, da sistematização e da racionalização. Sua utilização enquanto recurso de apoio epistemológico permitirá analisar as consequências da urbanização, e dos meios de transporte, no processo de expansão da prática do futebol na região do noroeste paulista.

O período em questão, além de muito rico em acontecimentos, foi bastante estudado pela historia e ciências sociais, a partir de diferentes referenciais teóricos. Para efeito deste texto, o entorno social, econômico e político do período é visto como uma fase de grandes transformaçōes e de acirramento de conflitos e contradiçōes, de diferentes naturezas, que virão a ter seu ápice na segunda metade do século com as tensões do fim do governo Goulart e os subsequentes governos militares. Não é possível aprofundar esta discussão nos limites de um artigo.

Vamos adotar aqui, em termos gerais, uma interpretação dos conflitos do período enquanto resultante de divergências entre os diferentes sujeitos sociais, no processo de busca racional da dominação para a obtençãa de benefícios materiais e simbólicos, evitando sobrepor as causas econômicas por cima das outras esferas de ação. Isto não significa, contudo, deixar de perceber como pano de fundo a concretude das lutas sociais, os efeitos de um processo de desenvolvimento assimétrico e uma distribuição desigual das oportunidades de vida entre os diferentes sujeitos sociais, estamentos e classes. A intenção é manter, para este texto, como referencia metodológica fundamental a lógica de análise apresentada por WEBER (1994) e sua releitura por historiadores importantes como, por exemplo, Sergio Buarque de Holanda ou Thomas Skidmore.

A contribuição conceitual mais interessante aqui, embora não necessariamente original, parece ser a inversão do sentido do movimento cultural, apontado no final, entre a cultura urbana e a rural. Existem trabalhos importantes que ilustram a influência da cultura rural, ou ainda caipira, na construção primeira do espaço urbano. Um exemplo é o texto de Florestan Fernandes (1998) intitulado "O Folclore de uma Cidade em Mudança". No ensaio aqui proposto, sem pretender comparar-se com nenhum dos autores citados, apresenta-se uma espécie de inversão, onde o trem traz para o interior aspectos de uma cultura urbana em construção, entre eles o esporte e, mais especificamente, o futebol. Não se trata, porém, de uma inversão no sentido forte do termo, já que em muitos casos a ferrovia será o elemento básico da fundação de um novo núcleo populacional, agregando populaçôes dos arredores com migrações internas. Mas, é importante destacar esta espécie de volta cultural da cidade para o interior, através do exemplo do futebol, enquanto elemento de análise e fio condutor de toda a reflexão.

Para facilitar a sua compreensão, a exposição foi dividida em tópicos, buscando em cada um deles o aprofundamento das questôes mais sensíveis ao tema. No primeiro tópico os aspectos políticos, sociais e econômicos do período serão levantados com a intenção de oferecer ao leitor tanto um panorama geral quanto as características mais específicas do período. No segundo tópico a urbanização e a industrialização são analisadas como partes integrantes da expansão do futebol. A tese defendida é que o fator chave para a relação: urbano, noroeste paulista e futebol são as ferrovias para escoar café. No próximo item o futebol no Brasil terá destaque, discutindo como ele foi se transformando de prática elitista para popular. Já no último tópico serão explicitados os caminhos dos trilhos e a relação com a prática do futebol no noroeste paulista. 
Este texto tem como objetivo colaborar e incentivar a discussões sobre os caminhos da prática esportiva e sua disseminação, tendo como referência uma região importante economicamente e que, no passado próximo, tinha uma inserção forte no cenário nacional de futebol.

\section{Aspectos políticos, sociais e econômicos do período}

Como afirmado anteriormente, o período analisado foi muito rico e marcou a passagem do Brasil monárquico para republicano, do Brasil com população predominantemente agrária para urbana, do Brasil do café para o da industrialização, do Brasil com autonomia estatal para um fortalecimento do poder Federal. Com toda esta riqueza de acontecimentos fica difícil, nos limites deste ensaio, descrever os contextos do período, por isso buscar-se-ão os aspectos mais relevantes para analisar as influências das ferrovias e da urbanização na disseminação do futebol pelo noroeste paulista.

No período anterior à Proclamação da República, em 1888, sob influência dos ideais republicanos e das ideias econômicas inglesas, acontece a Abolição da Escravatura. A partir desse momento há uma visível transformação do cenário político-social no Brasil, selando o fim de um período. Segundo uma leitura rápida, onde se destaca o desenvolvimento dos meios de produção e a necessidade de ampliação do mercado consumidor, os países que primeiro se industrializaram, com especial atenção à Inglaterra, influenciaram o governo brasileiro a abolir a escravidão. Logicamente que não somente a infra-estrutura econômica foi responsável por este processo, é necessário incorporar as consequências do Iluminismo e os princípios que moveram a Revolução Francesa. Pouco tempo depois, os ideais da Liberdade, Igualdade e Fraternidade chegaram aos países ultramarinos e em 15 de novembro de 1889, os militares, sob a figura de Marechal Deodoro da Fonseca, proclamam a República.

Dois grupos políticos deram base para a Revolução Republicana, os militares e os fazendeiros paulistas, representados pelo Partido Republicano Paulista. Este processo é fundamental para a industrialização, já que os monarquistas militavam por um Brasil monocultor, enquanto a elite paulista buscava a autonomia do país pelos ideais do liberalismo e da industrialização que já existia na Inglaterra e na Europa continental, inicia-se as bases políticas para desenvolvimento da economia liberal.

Com a Revolução Republicana ocorre uma transformação no modelo de sociedade. Os engenhos açucareiros, principal meio de produção de produto de exportação, são paulatinamente substituídos pelos latifúndios cafeeiros, e a mão-de-obra de origem africana ex-escrava começa a se misturar com a de origem europeia no cenário rural.

Outro fator importante para a vinda de mão-deobra estrangeira para São Paulo, e consequentemente uma maior diversidade cultural, era a autonomia política, territorial e econômica que davam aos governos estaduais uma maior liberdade para pedir empréstimo a nações estrangeiras ou adotar legislação regional específica para criação de empresas desses imigrantes, fato este que possibilitou os produtores de café e empresários paulistas a constituírem convênios diretamente com a Inglaterra para a produção e circulação das mercadorias, não é por mero acaso que São Paulo e não Rio de Janeiro, capital do país, que se inicia o futebol.

Estados como São Paulo, por exemplo, estavam habituados a negociar diretamente empréstimos estrangeiros, a serem utilizados para melhoramentos tais como ferrovias e portos, ou para financiamento de programa de proteção ao café (SKIDMORE, 1996, p.55).

Com o governo de Campos Sales (1898-1902) ficou estabelecida a base de um grande acordo político, a denominada Política do Café-com-Leite. Esta aliança de alternância da presidência nestes dois Estados possibilitou maior concentração de recursos para o investimento nas indústrias e consequentemente no escoamento dos seus produtos, Thomas Skidmore nos fala da importância do poder político para desenvolver a região, tanto dos bens de produção quanto da agricultura em grande escala, como foi o caso do noroeste paulista.

No ano de 1922 ocorreram reformas no setor cultural, com destaque para a Semana de Arte Moderna, representada por inúmeros artistas como Mario de Andrade, Oswald de Andrade, Tarsila do Amaral, Heitor Villa Lobos, Manuel Bandeira, Anita Malfati. Nas artes buscava-se uma ruptura com a cultura vigente. Os Modernistas criticavam o passadismo cultural que dominava as academias, os teatros e as políticas culturais do Estado Brasileiro do período. A cultura elitista que refletia a República Oligárquica exaltava um romantismo do século XIX europeu 
e descartava a cultura popular nacional. Um dos objetivos do movimento modernista brasileiro foi à exaltação desta cultura popular nacional, produzindo uma arte de conflito que apresentava os novos valores da industrialização, de um lado, e de outro, a cultura local sufocada pelo coronelismo (ALMEIDA, 2008).

A interpretação weberiana é que há uma incorporação neste período das práticas ditas elitistas na cultura popular brasileira; a arte como um dos arautos da aristocracia já necessitava de oxigenação. O mesmo se deu com a criação de clubes operários, exemplo disso é a Companhia Antártica Paulista que fica às margens da estação ferroviária da Mooca (bairro antigo da cidade de São Paulo), nas tecelagens da região do Brás, a criação do Esporte Clube Juventus, que não por acaso fica entre a Rua Javari e Rua dos Trilhos, onde passavam os operários que trabalhavam na região central da cidade paulista. Ocorre uma rápida disseminação da prática elitista para a popular, como foi nas artes e no futebol.

Nesse contexto um político do Rio Grande do Sul, Getulio Dornelles Vargas, que perdera as eleiçóes para a presidência, conseguiu o apoio dos militares de alta patente e do movimento tenentista (representa o popular sufocado pela aristocracia). Essa união permitiria as bases para a Revolução de 1930. Nas palavras de SKIDMORE (1996, p.23): "Alguns dos revolucionários, contudo, estavam menos dispostos a se satisfazerem com palavras, e finalmente organizaram uma conspiração integral, destinada a tomar o poder pela rebelião armada."

Durante o Governo Vargas houve uma aceleração no processo de industrialização, consequência da crise de 1929, pois ocorreu uma diminuição da capacidade de importar e um incentivo interno para a produção de bens de consumo e bens de produção. Vargas estimulou o desenvolvimento da rede de transportes para interligar as pessoas com as cidades e as mercadorias. A atenção para a legislação trabalhista e apoio aos operários também fizeram parte do governo Vargas.

O Brasil conseguiu crescer economicamente e passar de uma nação dependente da exportação agrícola para uma industrialização crescente, com impacto nos grandes centros urbanos primeiro, e o interior posteriormente. Vargas criou a Companhia Siderúrgica Nacional, a Agência Nacional de Petróleo, o Instituto Brasileiro de Geografia e Estatística (IBGE), a Usina Hidrelétrica do Vale do Rio São Francisco, a Companhia Vale do Rio Doce, além das obras de infra-estrutura e desenvolvimento do parque industrial brasileiro.

Ainda na década de 30 foram criadas instituições para formar uma elite capaz de contribuir para o aperfeiçoamento do governo e a melhoria do país, entre elas estão a Universidade de São Paulo (USP), Escola Livre de Sociologia e Política (ELSP) e a Universidade do Brasil (atual Universidade Federal do Rio de Janeiro).

Diante do período ditatorial do Estado Novo (1937-1945), Getulio fortalece o poder do Estado, tomando o controle da política, economia, cultura e da sociedade em geral. Em linhas gerais, o regime propunha a criação das condições consideradas necessárias para a modernização da nação: um Estado forte, centralizador, interventor, agente fundamental da produção e do desenvolvimento econômicos.

A propaganda do regime e a repressão aos seus opositores seriam duas faces do Estado Novo, muito bem representado pelo Departamento de Imprensa e Propaganda (DIP) (AlmeIDA, 2008). O DIP também tomou conta dos clubes sociais, e posteriormente os esportivos. O esporte era visto pelo governo como forma de distração, controle e formação de corpos preparados para o trabalho.

A política de urbanização e desenvolvimento foi efetiva e, quatro anos depois do fim do Governo Vargas, o país é comprovado como urbano por dados do IBGE. Essa urbanização e desenvolvimento foram fundamentais para o Esporte no país. Inserido neste universo de transformações, um aspecto econômico é fundamental para entendermos a revolução do esporte e, em particular, a evolução do futebol no país: as ferrovias. Elas levavam progresso sim, mas elas levavam principalmente pessoas e com elas as características desse novo universo urbano, com valores culturais diversos, cosmopolitismo e futebol. O próximo item tratará desses novos ares.

\section{Futebol e ferrovias: comopolitismo, integração e revolução}

A primeira linha férrea foi inaugurada em 1854 pelo Barão de Mauá. No ano seguinte teve o início da construção da estrada de ferro que ligaria o Rio de Janeiro à São Paulo (D. Pedro II). Nos velhos caminhos que cortavam o país partindo do litoral, antes frequentados pelas mulas cargueiras, expedições bandeirantes e índios, agora começavam a surgir estradas de metal em terrenos árduos, como planaltos, 
para desbravar o interior do Brasil para o oeste. Nas palavras de WiTTMANN (2001, p.35) a importância política e econômica de cada município começou a ser evidenciada "pelos trilhos em seu território".

A afirmação acima faz jus ao contexto econômico do Estado de São Paulo à época, no qual as linhas de ferro foram se enraizando pelo noroeste do território paulista com o objetivo claro de escoar as sacas de café para o litoral, sobretudo ao porto de Santos. Em 1867 foi concluída a construção da linha férrea que ligaria o porto de Santos a São Paulo e Jundiaí. AzEvedo (1950, p.28) coloca que essa estrada de ferro “é uma obra admirável de engenharia, quer pelo seu traçado, quer por suas obras de arte, por seus túneis, viadutos e muros de arrimo através da Serra do Mar”. A obra foi concluída pela São Paulo Railway, empresa responsável pelo trecho dessa linha. Segundo SAES (1981, p.41), "este fato marca o inicio da ligação ferroviária do Noroeste paulista ao porto de Santos." A ferrovia foi o instrumento do poder político das oligarquias paulistas e fator de acumulação de capital na medida em que podia conquistar o espaço físico, integrando o litoral às regiōes produtoras do Noroeste Paulista, e ao mesmo tempo costurar os interesses cafeeiros, atendendo também à expectativa de uma burguesia industrial urbana nascente (PASSOS, 2001, p.74).

Os fatos acima demonstram duas características essenciais para compreendermos o objetivo do trabalho, primeiro a industrialização da capital e o desenvolvimento do interior caminham com a construção de ferrovias para escoamento das mercadorias. Outro fato importante é que são as companhias inglesas, com seus engenheiros vindos da elite das Escolas Inglesas onde surgiram as primeiras regras do futebol, como afirma Norbert Elias e Eric DunNing (1992), que constroem as linhas férreas no noroeste paulista.

Durante a expansão cafeeira do final do século XIX, os fazendeiros - na maioria cafeicultores - da região do município de Araraquara (noroeste paulista), visavam escoar suas safras até os pólos comerciais exportadores. Com essa finalidade os latifundiários conseguiram junto a Companhia iniciar as obras de construção da estrada. A Companhia Paulista de Estradas de Ferro, que naquela época era detentora de toda a concessão na regiāo da Araraquarense por direito - herdado da Estrada de Ferro Rio Claro a São Carlos e Araraquara -, deu a necessária licença para a construção de uma nova estrada, ligando Araraquara a Ribeirãozinho (atual Taquaritinga). A construção foi autorizada pelo presidente do Estado, Bernardino de Campos em ofício datado de 12 de agosto de 1895. Chegando ao noroeste paulista em São José do Rio Preto em 1906. De 8 de fevereiro de 1916 até 15 de outubro de 1919 o acervo da estrada passa para as mãos de estrangeiros, que mudam a razão social para The São Paulo Northern Railroad Company sob a administração estrangeira. Posteriormente, o Presidente do Estado, Altino Arantes, decidiu desapropriá-la, conforme o decreto no 3.101 de 15 de outubro de 1919. Sob a administração do Estado de São Paulo, e com a denominação definitiva de Estrada de Ferro Araraquara.

A região noroeste do Estado de São Paulo foi de suma importância na produção de café durante o inicio do século XX até a Crise de 1929. A estrada de ferro Araraquara e Noroeste tinham a função de escoar café, importar produtos diversos e transportar pessoas. Este transporte de passageiros levou os pensamentos, os conhecimentos e as informaçôes vindas do leste, exatamente estes pensamentos que nos são importantes para compreendermos a expansão da prática de futebol no noroeste paulista.

Mas os caminhos de ferro não eram compostos apenas por trilhos, mas também por pontos de parada dos trens ou estaçóes. Nas redondezas das estaçóes nasciam pequenas vilas construídas pelos próprios funcionários que trabalhavam na manutenção das linhas, aglomerando casas que posteriormente poderia vir a tornar-se uma cidadela. Muitos dos funcionários que trabalhavam na manutenção eram oriundos da capital, dinamizando a cultura local com novos migrantes.

Com isso, a ferrovia ia alterando aos poucos a própria paisagem interiorana por onde se disseminava, conflitando a "cultura moderna" da capital com o "atraso e morbidez" do interior.

Todos os que habitam ao longo e na vizinhança dos caminhos, ficam sob a influência direta dos focos de irradiação de cultura, e tendem a transformar-se sob a pressão, mais ou menos intenso, dos elementos de cultura, material e espiritual que o comércio, as migrações e as viagens póem com freqüência ou constantemente em circulação (AzEVEDo, 1950, p.15).

É comum observar como algumas cidades do interior de São Paulo surgiram a partir das estações onde os trens paravam, já que os centros dessas cidades são muito próximos das estações ferroviárias e, consequentemente, essas redondezas são compostas por casas de estruturas e arquitetura muito antigas. Alguns exemplos são municípios como Araçatuba e São José do Rio Preto, ambas no noroeste do Estado de São Paulo.

Já se observou muitas vezes, por exemplo, a relação direta entre o caminho de ferro e as grandes aglomeraçôes urbanas e, portanto, o 
aumento da força de atração que desses centros se irradia além do território propriamente urbano, determinando, nas cercanias das cidades, um acréscimo quase igual da cifra da população. Se compararmos, de fato, as cidades que possuem uma estação ou são pouco distantes dela $(1500 \mathrm{~m})$ e as que são mais afastadas, verificamos que em geral nas primeiras o acréscimo anual da população é muito mais considerável e o excedente da imigração sobre a emigração é quase sempre maior nas primeiras do que nas segundas: a concentração da população é, pois, muito acentuada em torno das estações ferroviárias. (AzEVEDo, 1950, p.20).
Como afirmado anteriormente, a estrada de ferro tem um importante papel na disseminação dos novos pensamentos, porque tem como fundamento o encontro de pessoas de diferentes regiôes. Este sincretismo cultural possibilitou além de novos pensamentos políticos, econômicos e sociais, a prática do esporte. Antes de analisarmos a relação ferrovias e futebol, é importante compreender o fenômeno esportivo e sua relação com a indústria, o urbano e o transporte. $\mathrm{O}$ próximo tópico trabalhará com este tema, possibilitando a seguir fazer a análise interpretativa que relacionará as ferrovias, o desenvolvimento das cidades do noroeste paulista, a urbanização, a criação de clubes nas cidades e a prática do futebol.

\section{A gênese do Esporte Moderno e a prática do futebol no Brasil}

Houve uma evolução global dos códigos esportivos na mesma direção da urbanização da sociedade. Se compararmos os jogos populares no fim da Idade Média, com os jogos da Idade Moderna, veremos um aumento da burocracia e sistematização (LuCEnA, 2001). A regulamentação do esporte possibilitou passar de uma participação regional, para competições inter-regionais. Para isso criaram-se os clubes, que representavam cada região, facilitando a intermediação entre os participantes de várias localidades. Institucionalizou-se, burocratizou-se, racionalizou-se o jogo, com o fim último de dar aos participantes as mesmas chances. Podemos interpretar o acordo das regras como uma possível superioridade dos níveis de integração, permitindo a diminuição do uso da violência para formas mais comunicativas de relação social. Cabe reiterar que a construção das regras leva à criação de um organismo de fiscalização e representação.

O futebol é a modalidade esportiva mais popular no Brasil e tem sua origem na Inglaterra, assim como outras como "rugby" e "cricket". O futebol surgiu nos colégios ingleses a partir de adaptações do jogo com bola. $\mathrm{O}$ que começou como um jogo informal com finalidade de diversão passou a ter regras oficiais a partir de 1863, pela criação da Foot-ball Association, dando um caráter mais voltado à "seriedade do esporte" do que a "ludicidade do jogo".

Assim, o futebol era praticado dentro desses centros educacionais europeus por jovens com a finalidade de passatempo e manutenção do corpo saudável. Após ser bastante difundido dentre jovens de classe alta inglesa, chega à capital paulista com Charles Muller, trazendo consigo duas bolas de couro e um manual de regras e, sem imaginar de sua ação, surge um fenômeno sociocultural que abrangeria todas as camadas sociais no Brasil.

Histórias, como a do pioneiro, servem para atestar o caráter elitista dos primeiros tempos do esporte no Brasil: nascido somente pelo impulso de alguns grupos abastados, que buscavam na Europa as raízes de uma nova cultura e de uma nova civilização, para a recém-instaurada República brasileira (PEREIRA, 2000, p.22). Ilustra, assim, como o sujeito da ação social weberiano através de suas atitudes pode interferir em um contexto cultural particularizado.

Como a Inglaterra era a maior potência econômica naquele século, exportava para a Europa continental, Ásia e América seus produtos e tecnologia. Junto com uma mão-de-obra qualificada, chegavam também os pensamentos e ideais vigentes a outras localidades do mundo. Entre eles o futebol, concretizando a força do imperialismo britânico. Foi notória a influência inglesa sobre o Brasil. As indústrias, ferrovias, cidades, quase tudo era ligado direta ou indiretamente ao capital inglês.

Estes indivíduos, geralmente, estavam ligados à administração das primeiras empresas multinacionais do mundo que, na maioria, eram inglesas. Estes, portanto, eram burocratas que estavam espalhados pelo mundo com a função de cuidarem dos interesses econômicos de empresas que mantinham suas matrizes na Europa. Por causa deste perfil diferenciavam-se da grande massa de europeus imigrantes presentes, principalmente na América, como mão de obra fundamental para países como Brasil, Argentina, EUA. (AraúJo, 1996, p.73). 
Nessas empresas inglesas, descritas pelo autor, o patrono do futebol brasileiro insere a prática do esporte como passatempo. No mesmo ano de seu retorno ao Brasil tratou de organizar jogos com funcionários de empresas presentes na capital paulista, dentre elas: Companhia de Gás, São Paulo Railway e London Bank. O jogo serviu como demonstração para a imprensa paulistana e para a sociedade como um todo, principalmente para a camada mais abastada. Este foi o primeiro passo para institucionalizar a modalidade.
Já em 1901 surge a Liga Paulista de Football, associação cujo objetivo seria regulamentar competiçóes entre as equipes. Aos poucos as associaçōes foram se desenvolvendo e novos praticantes surgiram na capital, com o desenvolvimento da malha ferroviária o esporte, e particularmente o futebol, se difundiu para o interior. No noroeste paulista não foi diferente. Neste último tópico serão discutidos os aspectos principais desta difusão.

\section{O noroeste paulista a partir das fontes históricas}

No "Álbum Illustrado da Comarca de Rio Preto" é possível perceber a importância e esperança de desenvolvimento que as linhas de ferro trariam para São José do Rio Preto e cercanias. Esse sentimento de evolução é influenciado pelas pessoas que vivem nas grandes cidades da época e a cultura dos indivíduos que se deslocam pelo interior.

O parágrafo abaixo explicita bem esta esperança. Com as palavras típicas do interior, um barroco literário, descreve a impressão que o trem traria para aquelas, como descrito no Álbum (CAVALHeIro, 1929, p.12), "paragens":

Em 09 de Maio de 1912, reboou festivamente pelas quebradas dolentes daquelas campinas, o silvo crepitante da locomotiva. Havia todas as razōes para que o povo numa alegria delirante, festejasse $o$ auspicioso acontecimento da inauguração do tráfego na Estação local. Nesse dia, escrevia-se realmente uma das paginas mais fulgurantes da história de Rio Preto, e abriam-se aos seus destinos as portas largas do progresso, até então fechadas a todas as iniciativas.

Segundo Cavalheiro (1929, p.459) "todos sabiam que o mais pequeno esforço lograria a mais farta remuneração, mas era quase que temerária a conquista de terras tão distantes da civilização dos grandes centros, com os deficientes meios de comunicação que então existiam".

Talvez na capital São Paulo, a vinda do progresso já não fosse tão atrativa, já que o maior centro urbanoindustrial do início do século XX respirava avanços e tecnologias advindas do exterior, porém para a população que estava distante desses centros qualquer mudança no seu cotidiano abalaria toda a estrutura cultural na qual estava inserido. As estradas de ferro serviram como o meio pelo qual a urbanização e novas ideias chegaram até as cidades interioranas.

Vem finalmente a Estrada de Ferro, e com ella, vieram também novas correntes de actividade, que, incorporadas ás que já existiam, transformaram num relance, a vida pacata e monótona de Rio Preto, bem como a de todos os núcleos ainda em esboço por toda a area dos nossos dominios administractivos, resultando dahi, a indescriptivel si não phantastica actividade, que hoje podemos observar em todos os recantos da Comarca desdobrada em surtos de progresso (Cavalheiro, 1929, p.460).

As fontes históricas fazem imaginar o espanto, a felicidade e o medo de uma comunidade isolada das outras por falta de comunicação, vendo ao longe um carrilhão metálico deslizando por trilhos de ferro, fazendo um estridente barulho, anunciando a sua passagem por entre os campos. Além de despertar a curiosidade e os sonhos de caboclos, os trilhos nascem para poder transportar o café produzido pela mão-de-obra explorada composta de negros e imigrantes europeus. Os grandes latifundiários cafeeiros, visando apenas solucionar seus problemas econômicos, rasgam o interior com os caminhos de ferro sem imaginar as consequências que trariam e quanto modificariam a vida dos que habitavam as redondezas dos trilhos.

Dentre as consequências está a vinda do pensamento positivista, presente na capital do Estado, influenciando a industrialização e o desenvolvimento do interior, fazendo um elo entre ambos (capital e interior) por meio da ferrovia.

Como mencionado anteriormente, as estaçōes ferroviárias traziam recursos direta ou indiretamente para as pequenas cidades que eram cortadas pelas estradas. Um exemplo claro disso foi a cidade de Mirassol, distante aproximadamente 40 quilômetros de São José do Rio Preto, que sofre as influências da Estrada de Ferro Araraquara e chama a atenção de CAVALHEIro (1929, p.461), antes da metade do século XX: 
Mirassol (por exemplo) é o maior index de progresso de que haja memória em toda a historia das colonisações regionaes do Estado. Cidade com uma existência que mal attinge 20 annos após a sua fundação, lá está culminando em toda a pujança de sua belleza, como uma das mais sérias rivaes de todas as cidades da Araraquarense. Desde a edificação da cidade que é uma das mais bellas e modernas até à sua vida social que é uma das mais cultas, encontramos apenas motivos de assombro que naturalmente nos fazem pensar como será possível tamanho progresso realizado em tão curto prazo?

Por exemplo, Rio Preto, antes da estrada de ferro, contava apenas com cerca de 200 casas e uma população de pouco mais de mil habitantes. Transformou-se, em 20 anos, numa cidade com mil prédios e cerca de 30 mil habitantes (CAVAlHeiro, 1929, p.460).

Provavelmente este fenômeno de urbanização ocorreu em muitas cidades relacionadas com as ferrovias, seja apenas sendo cruzadas por elas ou com a presença de estações. No início da construção das estradas de ferro, as empresas que as construíam e administravam eram de origem inglesa ou com dependência do capital inglês. Não é demais afirmar que as tendências culturais e sociais inglesas influenciaram os indivíduos que trabalhavam nas empresas por eles administradas, como aconteceu na capital, segundo o "Álbum Illustrado da Comarca de Rio Preto", neste período iniciou-se a prática do futebol e a criação de clubes constituídos por sujeitos que tinham alguma relação com a ferrovia, como veremos mais adiante.

Após a volta de Charles Muller da Inglaterra para o Brasil, o esporte jogado com os pés, foi-se disseminando nas empresas de origem inglesa que estavam presentes na capital do Estado. Tanto é verdade que os times a disputar a primeira partida oficial de futebol em São Paulo foram o São Paulo Railway e a Companhia de Gás. Com os jogos surgiram os símbolos futebolísticos como os uniformes, os brasōes, a torcida e a agremiação, ou clube.

Os primeiros clubes foram criados sob a representação ou influência das empresas. Os trabalhadores jogavam no time da sua empresa, como exemplo, o London Bank e o São Paulo Railway. A partir desse momento os clubes da capital se organizam e começam a disputar jogos amistosos entre si. Dentre eles estavam São Paulo Athletic (clube criado pelo próprio Charles Muller), o Germânia (atual Esporte Clube Pinheiros), Mackenzie e a Internacional, já no ano de 1900. Em 1902 foi criada a Liga Paulista de Football com a função de organizar torneios entre os times já existentes na cidade.
No começo o futebol era praticado apenas por componentes da elite paulistana e existia preconceito com negros, explicado talvez pela origem européia do esporte e pelo processo transitório que o país passava, após a abolição recente da escravatura. Em paralelo ao campeonato organizado pela Liga Paulistana de Football, os operários das fábricas se organizavam e disputavam campeonatos de várzea.

Nessa perspectiva, a criação de clubes de futebol a partir das empresas se torna comum com o passar dos anos, e muitos clubes surgiram por interesse associativo de funcionários de empresas que administravam algumas ferrovias. Vejamos exemplos de alguns clubes do interior de São Paulo que surgiram entre 1900 e 1950 e tiverem relação direta ou indireta com as ferrovias.

Na cidade de São José do Rio Preto, o América Futebol Clube tem como fundador um engenheiro da Estrada de Ferro Araraquara que jogava futebol por "hobby". Segundo Ata de Fundação de 28 de janeiro de 1946, o engenheiro Antonio Tavares Pereira Lima foi eleito primeiro presidente da diretoria do América, com o intuito de abrir novos horizontes no cenário esportivo da cidade. No caso do América, como tantos outros, a ferrovia teve um direcionamento fundamental na sua criação, já que os dois principais idealizadores do projeto Antonio Tavarez e Vitor Buongermino se encontraram durante uma viagem de trem que partiu de Araraquara e tinha como destino a cidade de Rio Preto.

No noroeste paulista, mais precisamente na cidade de Araraquara, foi fundada a 12 de abril de 1950 a Associação Ferroviária de Esportes (AFE) por um grupo de engenheiros e servidores da Estrada de Ferro Araraquara. Um dos principais articuladores para a fundação deste clube foi o próprio Antonio Tavarez Pereira Lima, fundador do América Futebol Clube de Rio Preto. Os registros apontam como intenção do fundador erguer um clube esportivo de empregados da Estrada de Ferro Araraquara, sendo chamado de Associação Ferroviária de Esportes (AFE). A título de curiosidade, a principal cor da camisa do time era a mesma que a das locomotivas da empresa ferroviária que administrava a estrada, além do que a sigla do clube AFE (Associação Ferroviária de Esportes) tem relação com a EFA (Estrada de Ferro Araraquara).

Outro clube que teve relação com a malha ferroviária também é do interior paulista, porém não pertence à região noroeste. É a Associação Atlética Ferroviária de Botucatu. Na sua história de fundação os jogadores eram funcionários que trabalhavam na Estrada de Ferro Sorocabana.

O time de uma das cidades mais desenvolvidas da Região Nordeste, Ribeirão Preto, também foi criado 
com relação direta à ferrovia. No ano de 1918, o primeiro presidente do Botafogo de Ribeirão Preto, Joaquim Gagliano, era funcionário da Companhia Mogiana de Estradas de Ferro.

O Paulista Futebol Clube da cidade de Jundiaí foi talvez um dos clubes mais antigos a ser fundado sob influência das ferrovias. O clube foi fundado a 17 de maio de 1909 por funcionários da Companhia Paulista de Estradas de Ferro (CPEF), contudo o clube sucedia ao Jundiahy Foot Ball Club fundado por um escocês em 1903, chamado Thomas Scott. O próprio estádio do Paulista chama-se Jayme Cintra, em homenagem ao engenheiro que trabalhou por décadas na $\mathrm{CPEF}$.

$\mathrm{O}$ time de futebol mais antigo do Brasil, Ponte Preta, também surgiu do desenvolvimento urbano industrial. Em 1900, na cidade de Campinas, jovens praticavam o futebol às margens da ferrovia, próximos ao colégio Culto à Ciência fundaram o clube para praticar futebol, a Associação Atlética Ponte Preta.

\section{Considerações finais}

É espantoso ver como o futebol passou de um esporte elitista no começo do século, a um esporte abrangente e disseminado na metade do século XX, como ilustra a realização da Copa do Mundo. A popularização dessa modalidade foi rápida se compararmos com outras modalidades como o "rugby", por exemplo, tão antigo quanto o futebol e também praticado pelos ingleses já no século XIX.

Existem muitas vertentes sobre o surgimento do futebol no Brasil, mas a hipótese de que Charles Muller foi o incentivador e responsável é a mais aceita por historiadores e fontes espalhados na literatura. Faz sentido que a cidade de São Paulo, onde estava presente uma grande porcentagem das empresas inglesas existentes no Brasil, fosse o pólo disseminador da modalidade.

A questão fundamental desta pesquisa foi apresentar a influência da urbanização e da industrialização na prática e disseminação de uma modalidade específica que
$\mathrm{Na}$ cidade de Campinas outro clube fora fundado com participação de ferroviários, como se encontra na ata de fundação do clube Guarani em 1911, em homenagem ao maestro Carlos Gomes, que escrevera a ópera "O Guarani”, o nome oficial do clube fora "Guarany Foot-Ball Club".

É difícil precisar quantos clubes, fundados pelo interior de São Paulo, possuíam ou possuem relação direta ou indireta com a ferrovia, mas não é um fenômeno isolado. Talvez muitos outros clubes que se originaram nesses moldes já não existam mais, em decorrência de fatores econômicos, administrativos ou pela própria desvalorização que o transporte ferroviário teve na segunda metade do século XX. Apesar da estatização de algumas ferrovias por volta dos primeiros anos do século passado, algumas empresas passaram por más administrações e sucumbiram ao tempo. A própria política de desenvolvimento do setor automobilístico com Juscelino Kubitschek fez com que a malha ferroviária sofresse sucateamento.

trafegou pela malha ferroviária do noroeste paulista. Apresentou-se também o futebol como algo praticado pelos operários, e não por camponeses. Aprofundar o estudo desta relação futebol/operários pode vir a ser importante para compreendermos melhor o fenômeno do esporte na sua abrangência macro.

Outro ponto que merece destaque é o surgimento dos clubes como cultura industrial, já que não há registro de criação de clubes, neste primeiro momento, pelos latifundiários do café. Os principais clubes têm ligação direta ou indireta com as indústrias e, principalmente, com as ferrovias.

Conclui-se a importância da urbanização na disseminação do esporte pelo País. Passado mais de um século da chegada do futebol no Brasil ainda se pode visualizar os principais clubes presentes nos centros urbanos mais industrializados com destaque, principalmente, do Estado de São Paulo no cenário nacional.

\begin{abstract}
Football and rail: a train of industrialization that the northwest part paulista.

The article seeks to develop the relationship between the expansion of railway network in São Paulo and the evolution of sports, especially the soccer. The central idea is that movement occurs in urban areas to the interior, not as a traditionally rural area, but in the midst of the emergence and expansion of towns
\end{abstract}


and cities. It identifies the main features of political scenario, economic and social in Brazil in the first half of the twentieth century and contribute to the discussion on the development of sports in the period.

UNITERMS: History; Sports; Football.

\section{Referências}

ALMEIDA, M. Análise do desenvolvimento das práticas urbanas de lazer relacionadas a produção cultural no período nacional-desenvolvimentista à globalização através da "Teoria da Ação Comunicativa". Tese (Doutorado) Faculdade de Educação Física, Universidade Estadual de Campinas, Campinas, 2008.

ALMEIDA, M.; GUTIERREZ, G. Políticas públicas de lazer e qualidade de vida. In: VILARTA, R. (Org.). Qualidade de vida e políticas públicas. Campinas: IPES, 2004.

ARAÚJO, J.R.C. Imigração e futebol: O caso Palestra Itália. 1996. 179 f. Dissertação (Mestrado) - Departamento de Sociologia, Universidade Estadual de Campinas, Campinas, 1996.

AZEVEDO, F. Um trem corre para o oeste: estudo sobre o noroeste e seu papel no sistema de viação nacional. 2. ed. São Paulo: Martins, 1950.

CAVAlHeiro, A.A. (Org.). Album illustrado da Comarca de Rio Preto. São Paulo: Duprat-mayenã, 1929. (Propaganda Regional do Estado de São Paulo).

ELIAS, N.; DUNNING, E. A busca da excitação. Lisboa: Difusão Editorial, 1992

FERNANDES, F. O folclore de uma cidade em mudança. In: OLIVEIRA, P.S. (Org.). Metodologia das ciências humanas. São Paulo: Hucitec/UNESP, 1998

LUCENA, R.F. O esporte na cidade: aspectos do esforço civilizador brasileiro. Campinas: Autores Associados, 2001. PEREIRA, L.A.M. Footballmania: uma história social do futebol no Rio de Janeiro, 1902-1938. São Paulo: Nova Fronteira, 2000. PASSOS, L.M.V. Mulheres, trens e trilhos: modernidade no sertão paulista. Bauru: Edusc, 2001.

SAES, F.A.M. As ferrovias de São Paulo 1870-1940: expansão e declínio do transporte ferroviário em São Paulo. São Paulo: Hucitec, 1981.

SKIDMORE, T. Brasil: de Getúlio Vargas a Castelo Branco (1930-1964). 10. ed. Rio de Janeiro: Paz e Terra, 1996. WEBER, M. Economia e sociedade: fundamentos da sociologia compreensiva. Tradução de Regis Barbosa e Karen Elsabe Barbosa. 3. ed. Brasília: Editora Universidade de Brasília, 1994

WITTMANN, A.C.R. A estrada de ferro no Vale do Itajaí: resgate do trecho Blumenau - Warnow. Blumenau: Edifurb, 2001.

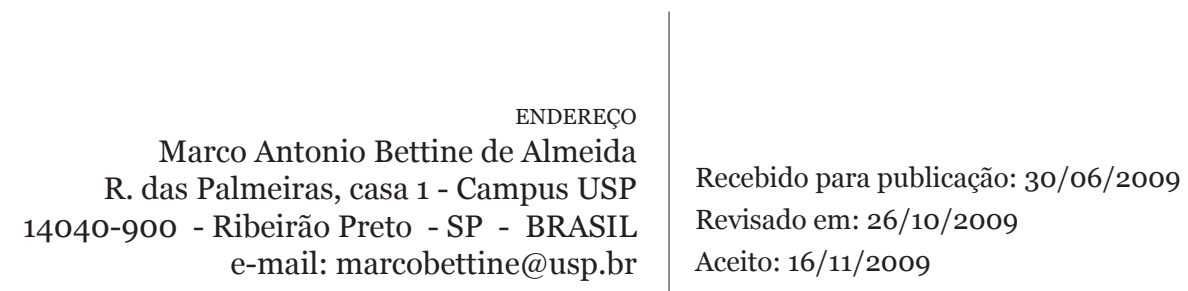

258 • Rev. bras. Educ. Fís. Esporte, São Paulo, v.24, n.2, p.249-58, abr./jun. 2010 